\title{
Epidemiologic Characteristics of Patients with Cerebral Palsy
}

\author{
Fatma Fidan ${ }^{*}$, Ozlem Baysal2 \\ ${ }^{1}$ Department of Physical Medicine and Rehabilitation, Yildirim Beyazit University Faculty of Medicine, Ankara, \\ Turkey \\ ${ }^{2}$ Department of Physical Medicine and Rehabilitation, Inönü University Faculty of Medicine, Malatya, Turkey \\ Email: ${ }^{*}$ drfatmafidan@hotmail.com
}

Received 25 June 2014; revised 26 July 2014; accepted 10 August 2014

Copyright (C) 2014 by authors and Scientific Research Publishing Inc.

This work is licensed under the Creative Commons Attribution International License (CC BY). http://creativecommons.org/licenses/by/4.0/

(c) (i) Open Access

\section{Abstract}

Aim: The aim of this study was to determine the demographical and clinical features of patients with cerebral palsy (CP) attending to our outpatient or inpatient clinics. Materials and Methods: Children admitted to Inonu University Faculty of Medicine Department of Physical Medicine and Rehabilitation outpatient or inpatient clinics, Malatya, Turkey with the diagnosis of CP during the study period were included in the study. Age, sex, etiological factors, clinical classifications, and epidemiological characteristics such as socio-economic status as well as the problems associated with CP were analyzed in all patients. Results: Of the total of 130 patients with mean ages $51.05 \pm 36.06$ months, 51 were girls and 79 were boys. The most common etiologic risk factors were bleeding and presence of threatened miscarriage in prenatal period; asphyxia, low birth weight and prematurity in perinatal period; and neonatal convulsions and hyperbiluribinemia in the postnatal period. Consanguineous marriage was present in $24.6 \%$ of families. In clinical classification it was seen that 45 subjects were spastic quadriplegic (34.6\%), 41 were spastic diplegic $(31.5 \%), 15$ were dyskynetic $(11.5 \%), 14$ were spastic hemiplegic $(10.8 \%), 10$ were mixed type $(7.7 \%)$ and 5 were hypotonic/ataxic $(3.8 \%)$. Conclusion: Prenatal risk factors constitute the foremost risk factors in CP etiology. CP incidence can be lowered by close follow up of the newborns who has been considered as high risk newborns due to the presence of risk factors during pregnancies or deliveries, and by increasing the number of neonatal intensive care units. Besides, it is important to raise public awareness about consanguinity marriages in our country.

\section{Keywords}

Cerebral Palsy, Epidemiology, Etiology

\footnotetext{
"Corresponding author.
} 


\section{Introduction}

Cerebral palsy (CP) is a well-recognized neurodevelopmental disability characterized by disorders in movement, muscle tone and posture resulting from a nonprogressive damage to the immature brain tissue. Voluntary motor activity impairments and sensorial dysfunctions develop as a consequence [1] [2]. Except from neuromotor control disorders, visual impairments, hearing impairments, communication problems, feeding problems, seizures and cognitive impairments may also be observed in CP [3].

Although different incidence rates have been reported so far, CP is one of the most common causes of disability in children with a mean incidence of 2 - 3 per 1000 live births in many populations [1] [4]. In a recent study conducted in children aged between 2 - 16 years, CP prevalence was reported to be 4.4 per 1000 live births in our country [5].

Brain damage leading to CP may develop either in prenatal, perinatal or postnatal period. Most common etiologic factors are prematurity, ischemia, hypoxemia, hyper bilirubinemia and trauma [1] [6]. Since improvements and advances in neonatal care significantly reduced the neonatal mortality rates in developed countries, $\mathrm{CP}$ risk was accordingly increased due to the increased survival of high-risk premature and low birth weight newborns [6] [7].

Early diagnosis and treatment of CP are particularly important in successful rehabilitation. The aim of CP rehabilitation is to minimize the handicap by maximizing the motor control, functional level, intellectual level, social participation and independence of the child [8] [9].

Having knowledge about epidemiologic characteristics of the disease incidence of which can not be underestimated in general population, will be beneficial in terms of both treatment and prevention. Therefore we aimed to determine the demographical and clinical characteristics of children with CP who admitted to our inpatient or outpatient clinics in eastern part of Turkey.

\section{Materials and Methods}

The study comprised 130 children with the diagnosis of CP aged between 9 months - 14 years who had been under follow-up at Inonu University Faculty of Medicine Department of Physical Medicine and Rehabilitation outpatient or inpatient clinics, Malatya, Turkey. All parents gave written informed consents and study was conducted according to Declaration of Helsinki. After obtaining detailed medical histories from their parents, careful musculoskeletal and neurological examinations were performed by the same physiatrist.

Age, gender, maternal age and profession, paternal age and profession, detected etiological factors, concomitant problems (including visual impairments, hearing impairments, speech disorders, feeding problems and cognitive impairments) and epidemiological characteristics of the patients were assessed. Sociodemographical characteristics of the patients' and their families, information about the diagnosis and subsequent therapies, and detailed histories of prenatal/perinatal/postnatal period were gathered from face-to-face interviews and from medical records. Presence of deformities, spasticity and concomitant problems were determined after performing detailed musculoskeletal and neurological examinations. Cranial magnetic resonance imaging findings were also recorded if available. Etiological classifications were made regarding the prenatal, perinatal, and postnatal risk factors.

Clinical classifications were done according to Hagberg's [10] classification. Patients were groupped into following categories:

1) Spastic quadriparesic $C P$,

2) Spastic diplegic CP,

3) Spastic hemiplegic $C P$,

4) Dyskinetic CP,

5) Hypotonic-ataxic CP,

6) Mixt type CP.

Data analysis was performed using "SPSS" statistical software package. For Windows. Chi-square test was used for statistical comparison. Statistical significance was set at $\mathrm{p}<0.05$.

\section{Results}

A total of 130 children were included in the study. Mean age was $51.05 \pm 36.06$ months ( 9 - 168 months), 79 were boys (60.8\%) and 51 were girls (39.2\%) with a boys/girls ratio of 1.54 . There was no statistically signifi- 
cant difference between boys and girls in distribution of cases by age groups, most of the cases were at 2 - 5 (43.9\%) age group (Table 1 ).

It was seen that $96.9 \%$ of the mothers were housewives and most of the fathers were officers or self-employers. Educational levels of fathers were significantly higher than the mothers. Consaguinous marriages were present in $24.6 \%$ (32) of the families. Regarding the socioeconomical level, 50\% (65) had low, $24.6 \%$ (32) had medium and $25.4 \%$ (33) had high socioeconomical conditions.

Regarding the clinical classifications of our patients, most of the cases were spastic quadriplegics with the ratio of $34.6 \%$ (45), followed by spastic diplegics (31.5\%, 41 cases), dyskitenics (11.5\%, 15 cases), spastic hemiplegics (10.8\%, 14 cases), mixt types (7.7\%, 10 cases) and hypotonic/ataxics (3.8\%, 5 cases), respectively (Table 2).

Regarding etiological risk factors; threat of miscarriage and vaginal bleeding was the most common risk factors in prenatal period $(20.8 \%, \mathrm{n}=27)$; asphyxia $(52.3 \%, \mathrm{n}=68)$, low birth weight $(41.5 \%, \mathrm{n}=54)$ and prematurity $(35.4 \%, n=46)$ in perinatal period; and neonatal convulsions $(18.5 \%, n=24)$ and neonatal hyperbilirubinemia $(14.6 \%, n=19)$ in the postnatal period. Etiologic factors could not be determined in $10 \%(n=13)$ of the cases (Table 3). When the distribution of the etiological factors in the clinical classifications were assessed, asphyxia and difficult deliveries were most common in spastic quadriplegic $\mathrm{CP}$, prematurity and low birth weight in spastic diplegic $\mathrm{CP}$, and neonatal hyperbiluribinemia in dyskinetic CP.

Ninety-two (70.8\%) children were not ambulatory and 38 (29.2\%) were ambulating with support or independently. It was seen that 4 children were using oral baclofen and one was using tizanidine. Botulinum toxin injections were performed in 9 cases and one child was using oral baclofen in addition to botulinum toxin injection. There was intrathecal baclofen pump in one child. Forty-eight cases (36.9\%) were using medical treatments, most of which were antiepileptic drugs (41 cases).

Among concomitant problems, oral-motor dysfunctions (sucking difficulties, swallowing disorders, chewing problems, drooling, dysarthria) were present in $54.6 \%(\mathrm{n}=71)$, visual problems (strabismus, hemianopsia) in 45.4\% ( $n=59)$, dental problems (enamel problems, malocclusion, tooth decays, tooth gum hyperplasia) in 43.1\% ( $n=56)$, epilepsy in 36.1\% ( $n=47)$, mental retardation in $35.4 \%(n=46)$, involuntary movements in $23.1 \%(n=30)$, gastrointestinal problems (vomiting, constipation) in $20 \%(n=26)$, hearing loss in $11.5 \%(15)$ and pulmonary problems in 9.2\% $(n=12)$ of the patients (Figure 1$)$.

Among musculoskeletal problems, foot deformities were detected in 56.1\% $(\mathrm{n}=73)$, kyphosis in $12.3 \%(\mathrm{n}=$ 16), scoliosis in $21.5 \%(\mathrm{n}=28)$, knee deformities in $6.2 \%(\mathrm{n}=8)$ and some other problems in $2.3 \%(\mathrm{n}=3)$ of the patients (Figure 2).

Table 1. Demographical characteristics of patients.

\begin{tabular}{cccc}
\hline & & $\begin{array}{c}\text { Number of patients } \\
\mathbf{n}=\mathbf{1 3 0}\end{array}$ & $\begin{array}{c}\text { Percentage } \\
\mathbf{\%}\end{array}$ \\
\hline \multirow{2}{*}{ Gender } & Boys & 79 & 60.8 \\
& Girls & 51 & 39.2 \\
Age (years) & $0-1$ & 6 & 4.6 \\
& $1-2$ & 30 & 23 \\
& $2-5$ & 57 & 43.9 \\
\hline
\end{tabular}

\section{Table 2. Cerebral palsy types.}

\begin{tabular}{ccc}
\hline Type & Number of patients (n) & Percentage (\%) \\
\hline Spastic quadriparesic & 45 & 34.6 \\
Spastic diplegic & 41 & 31.5 \\
Spastic hemiplegic & 14 & 10.8 \\
Dyskinetic & 15 & 11.5 \\
Hypotonic-ataxic & 5 & 3.8 \\
Mixt type & 10 & 7.7 \\
\hline
\end{tabular}


Table 3. Risk factors.

\begin{tabular}{lcc}
\hline \multicolumn{1}{c}{ Risk factors } & Number of patients (n) & Percentage (\%) \\
\hline Prenatal & 27 & 20.8 \\
- $\quad$ Threat of miscarriage or vaginal bleeding & 12 & 9.2 \\
- $\quad$ Maternal disease & 9 & 6.9 \\
- $\quad$ Multiple gestation & & \\
Perinatal & 68 & 52.3 \\
- $\quad$ Asphyxia & 54 & 41.5 \\
- $\quad$ Low birth weight & 46 & 35.4 \\
- $\quad$ Prematurity & 44 & 33.8 \\
- $\quad$ Difficult delivery & & \\
Postnatal & 24 & 18.5 \\
- Neonatal convulsion & 19 & 14.6 \\
- $\quad$ Neonatal hyperbilirubinemia & 13 & 10 \\
- Neonatal infection & 5 & 3.8 \\
- Intracraniyal hemorrhage & 13 & 10 \\
\hline
\end{tabular}

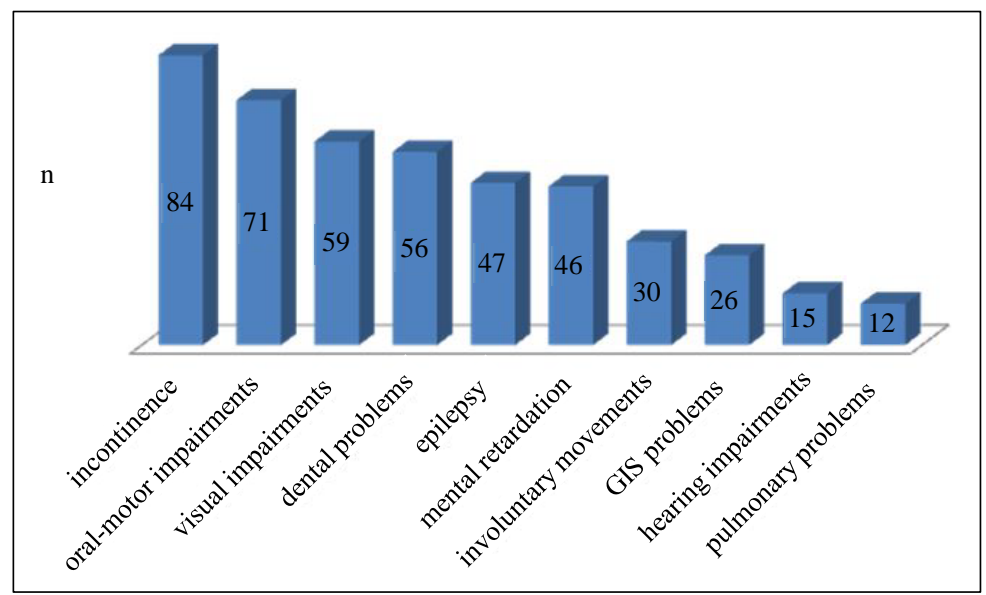

Figure 1. Concomitant problems in patients. n: number of patients.

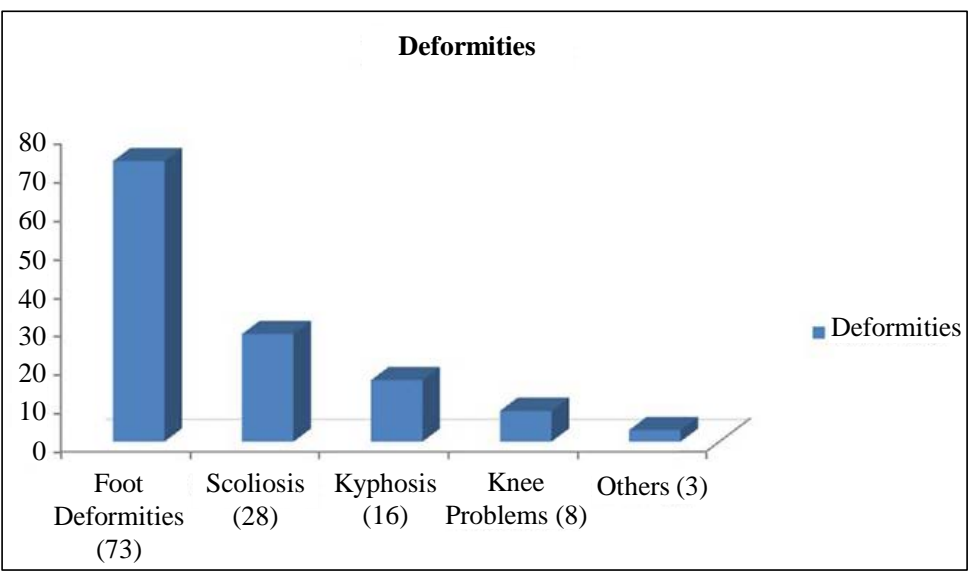

Figure 2. Musculoskeletal deformities in patients. 
MRI scans were available in 104 patients and 94 of them revealed various pathologies, while remaining 10 were normal. Periventricular leukomalacia (PVL) was seen in 58 cases, unilateral (focal) infarcts in 8, multiple infarcts in 7 and other findings (i.e., cerebral atrophy, hydrocephalia, cerebral hemiatrophy, involvement of basal ganglia and thalamus ) in 21 cases.

\section{Discussion}

CP is the most common cause of neuromuscular disabilities of childhood in worldwide which can cause permanent disability, therefore it is very important to establish diagnosis, to initiate appropriate treatment/rehabilitation programme and to educate the patient's family as soon as possible [3]. Well-recognition of epidemiologic characteristics will obviously provide benefits not only in prevention, but also in treatment of the disease.

$\mathrm{CP}$ can affect both genders, however boys are affected slightly higher than girls. In this current study, we observed that 79 of our 130 patients were boys with a boy/girl ratio of 1.54. Similarly, Okan et al. [11] reported a boy/girl ratio of 1.56 in their study which was also conducted in our country. Consistent with these results, Johnson et al. [12] reported boy/girl ratio as 1.33 in Europea and Laisram et al. [13] reported as 1.9 in India.

Although having kin relationships between parents is not directly associated with development of $\mathrm{CP}$, it should be kept in mind that it can be a predisposing risk factor and can enhance the overall risk. Therefore, it is important to raise the awareness of the community about consanguineous marriages. In several studies conducted on CP patients in our country, Hamamc1 et al. [14] reported the ratio of consanguineous marriages as 26\%, Eriman et al. [7] as 25\%, and Erkin et al. [15] as 23.8\%. Likewise, this ratio was $24.6 \%$ in our study.

Clinical classification categorizes CP as spastic (quadriparesic, diplegic, hemiplegic), hypotonic/ataxic, dyskinetic ve mixt-type CP [10]. The most common types are the spastic types in worldwide. Similarly, most of our patients (76.9\%) were spastic CP. However, the distribution of the clinical subtypes of our spastic CP patients differed from the results of western countries. In our study, 34.6\% of our cases were spastic quadriparesic and 31.5\% were spastic diplegic. Eriman et al. [7] evaluated 202 patients with CP and similar to our results they reported that 34\% was spastic diplegic and 32\% was spastic tetraplegic. Whereas, in European countries spastic diplegia is seen in significantly higher rates. Studies reported the ratio of spastic quadriparesic CP as $18 \%$ 20.8\% and spastic diplegic CP as 40.9\% - 54.9\% in Europen countries [12] [16] [17]. The probable explanations of this finding may be the decreased perinatal mortality of premature babies as a result of more available and equipped newborn intensive care units in western countries and observed differences in predisposing risk factors in-between.

Dyskinetic CP ratio was $11.5 \%$ in our study. Özmen et al. [18] reported this ratio as $18.2 \%$ and Okan et al. [19] as $16.1 \%$ in Turkey. However, in European countries, it was reported as 6.5\% [12]. The higher ratio in our country may partly be due to the lack of awareness of families regarding neonatal hyperbilirubinemia and the delay to seek for medical care due to misthinking it as physiological jaundice.

In distribution of etiological factors it was seen that perinatal risk factors including asphyxia $(52.3 \%, \mathrm{n}=68)$, low birth weight $(41.5 \%, \mathrm{n}=54)$ and prematurity $(35.4 \%, \mathrm{n}=46)$ were significantly more common in this current study. In other studies conducted in Turkey; Erkin et al. [15] determined the low-birth weight (45.1\%), prematurity (40.5\%) and asphyxia (34.6\%); Öneş et al. [20] determined the low birth weight (41.59\%), anoxia (41.59\%) and prematurity (35.40\%), and Demir et al. [21] determined the asphyxia (39.2\%) and prematurity (25.5\%) as the most common risk factors. It was observed that the foremost risk factors were the perinatal risk factors in our country. We assume that CP incidence can effectively be lowered by improving the pregnancy monitoring and by increasing the standarts of delivery rooms, delivery teams and neonatal intensive care units.

When the distribution of etiological factors in clinical classification is assessed, it is remarkable that asphyxia and difficult deliveries are more common in spastic quadriparesic CP, prematurity and low birth weight in spastic diplejic CP and neonatal hyperbiluribinemia in dyskinetic CP.

Various deformities due to spasticity and muscle imbalance may develop in children with CP. The most common of these are kyphosis, scoliosis, hip dislocations, knee flexion contractures, pes equinus, pes valgus and pes equinovarus deformities. Eriman et al. [7] detected foot deformities to be the most common (45.5\%), followed by spinal deformities (13.8\%). Similarly, we also observed that foot deformities were the most common deformity in our patients with a ratio of $56.1 \%$, followed by scoliosis (21.5\%) and kyphosis $(12.3 \%)$, respectively.

Various concomitant problems such as visual impairments, speech disorders and hearing impairments can be seen as well as motor impairments in children with CP. Impairments in development and coordination of facial 
muscles, especially of perioral muscles, result with deterioration of sucking, swallowing and speech articulation. Besides, due to lack of coordination in the oral muscles, severe feeding problems and salivary problems may develop [20]. Consistent with the literature, the most common accompanying problem was oral-motor disorders (in 54.6\% of our patients) while visual impairment was the second (45.4\%). It was found that concomitant problems including speech disorders, visual problems, epilepsy and mental retardation were more common in spastic quadriparesic CP, while hearing loss was more common in dyskinetic CP.

Pueyo et al. [22] reevaulated their studies on brain lesions in CP performed by using using structural and functional imaging techniques and made some conclusions. They reported that mainly periventricular white matter was affected in spastic diplegic CP. They also stated that corpus callosum hypoplasia as well as cortical and subcortical lesions were present in spastic quadriplegia. Unilateral lesions were found to be more common in hemiplegic types. Dyskinetic CP was characterized either with pathologic changes in basal ganglia and thalamus or absence of any lesion. In our study we observed that PVL was present in 32 of 36 spastic diplegic, dysgenesis of corpus callosum in 27 of 34 spastic quadriparesic, unilateral infarcts in 8 of 10 spastic hemiplegic, and involvement of basal ganglia and thalamus in 6 of 11 dyskinetic CP patients.

There are some limitations of our study. Major limitation is the relatively small number of patients included. Further studies including larger number of patients will give more precious results. Secondly, we didn't use gross motor function classification system in our patients since functional evaluation was beyond the aims of the present study.

\section{Conclusion}

To conclude, it was observed that perinatal factors were the leading risk factors in CP etiology. We assume that CP incidence can effectively be lowered by improving the pregnancy monitoring and by increasing the standards of delivery rooms, delivery teams and neonatal intensive care units. Besides, consanguineous marriage rates in our country cannot be underestimated, therefore raising the public awareness regarding consanguineous marriages is of particular importance. Finally; although CP is not a curable disease, rehabilitation, special education and psycho-social support may significantly reduce the problems and may provide reintegration of the child into the community. Therefore, timely diagnosis and initiation of appropriate rehabilitation programmes should be ensured.

\section{Conflict of Interest}

There is no conflict of interest.

\section{References}

[1] Matthews, D.J. and Wilson, P. (1999) Cerebral Palsy. In: Molnar, G.E. and Alexander, M.A., Eds., Pediatric Rehabilitation, 3rd Edition, Hanley and Belfus Inc., Philadelphia, 193-217.

[2] Simsek, I. (2000) Serebral Palsi. In: Beyazova, M. and Gokce-Kutsal, Y., Eds., Fiziksel Tip ve Rehabilitasyon, Gunes Kitabevi, Ankara, 2395-2439.

[3] Dormans, J., Susman, M., Ozaras., N. and Yalcin, S. (2000) Serebral Palsi Tedavi ve Rehabilitasyon. Mas Matbaacilik, Istanbul.

[4] Dursun, N. (2004) Serebral Palsi. In: Oguz, H., Dursun, E., Dursun, N., Eds., Tıbbi Rehabilitasyon, Nobel Tip Kitapevleri, Istanbul, 957-974.

[5] Serdaroglu, A., Cansu, A., Özkan, S. and Tezcan, S. (2006) Prevalance of Cerebral Palsy in Turkish Children between the Ages of 2 and 16 Years. Developmental Medicine Child Neurology, 48, 413-416. http://dx.doi.org/10.1111/j.1469-8749.2006.tb01288.x

[6] Gans, B.M. and Christopher, R.P. (1998) Rehabilitation of the Pediatric Patient. In: DeLisa, J.A., Ed., Rehabilitation Medicine, 3rd Edition, J.B. Lippincott Co., Philadelphia, 929-951.

[7] Eriman, E.O., Icagasıoglu, A., Demirhan, E., Kolukısa, S., Aras, H., Haliloglu, S. and Baklacioglu, H.S. (2009) Serebral Palsili 202 Olgunun Demografik Verileri ve Klinik Özellikleri. Türkiye Fiziksel Tip ve Rehabilitasyon Dergisi, 55, 94-97.

[8] Livanelioglu, A. (1993) Serebral Paralizi ve Rehabilitasyonu. Ozurlu Cocuklar Rehabilitasyon ve Egitim Sempozyumu, Ankara, 5-11.

[9] Stempien, L.M. and Gaebler-Spira, D. (1996) Rehabilitation of Children and Adult with Cerebral Palsy. In: Braddom, 
R.L., Ed., Physical Medicine and Rehabilitation, W.B.Saunders Co., Philadelphia, 1113-1132.

[10] Hagberg, B., Hagberg, G. and Olow, I. (1993) The Changing Panaroma of Cerebralpalsy in Sweden. I. Prevelance and Origin during the Birth Year Period 1983-1986. Acta Paediatrica, 82, 387-393. http://dx.doi.org/10.1111/j.1651-2227.1993.tb12704.x

[11] Okan, N., Okan, M., Eralp, O. and Aytekin, A.H. (1995) The Prevalance of Neurological Disorders among Children in Gemlik (Turkey). Developmental Medicine Child Neurology, 37, 597-603. http://dx.doi.org/10.1111/j.1469-8749.1995.tb12048.x

[12] Johnson, A. (2002) Prevalance and Characteristics of Children with Cerebral Palsy in Europe. Developmental Medicine Child Neurology, 44, 633-640. http://dx.doi.org/10.1017/S0012162201002675

[13] Laisram, N., Srivastava, V.K. and Srivastava, R.K. (1992) Cerebral Palsy—An Etiological Study. Indian Journal of Pediatrics, 59, 723-728. http://dx.doi.org/10.1007/BF02859408

[14] Hamamci, N., Gokce-Kutsal, Y. and Altıoklar, K. (1991) Spastik Serebral Palsili Hastalarda Yurume Analizi. Romatoloji ve Tibbi Rehabilitasyon Dergisi, 3, 169-178.

[15] Erkin, G., Delialioglu, S.U., Ozel, S., Culha, C. and Sirzai H. (2008) Risk Factors and Clinical Profiles in Turkish Children with Cerebral Palsy: Analysis of 625 Cases. International Journal of Rehabilitation Research, 31, 89-91. http://dx.doi.org/10.1097/MRR.0b013e3282f45225

[16] Bottos, M., Granato, T., Allibrio, G., Gioachin, C. and Puato, M.L. (1999) Prevalence of Cerebralpalsy in North-East Italy from 1965 to 1989. Developmental Medicine Child Neurology, 41, 26-39. http://dx.doi.org/10.1017/S0012162299000067

[17] Kavcic, A. and Perat, M.V. (1998) Prevalence of Cerebral Palsy in Slovenia: Birth Years 1981 to 1990. Developmental Medicine Child Neurology, 40, 459-463. http://dx.doi.org/10.1111/j.1469-8749.1998.tb15396.x

[18] Ozmen, M., Calıskan, M., Apak, S. and Gokcay, G. (1993) 8 Year Clinical Experience in Cerebral Palsy. Journal of Tropical Pediatrics, 39, 52-54. http://dx.doi.org/10.1093/tropej/39.1.52

[19] Okan, M., Eralp, O. and Donmez, O. (1995) Bursa Yoresinde İnfantil Serebral Parezinin Ozellikleri ve Eslik Eden Norolojik Semptomlar. Istanbul Tip Fakultesi Mecmuası, 58, 41-44.

[20] Ones, K., Celik, B., Caglar, N., Gultekin, O., Y1lmaz, E. and Cetinkaya, B. (2008) Serebral Palsi Polikliniğine Müracaat Eden Hastaların Demografik ve Klinik Ozellikleri. Türkiye Fiziksel Tip ve Rehabilitasyon Dergisi, 54, $13-16$.

[21] Demir, H., Eser, C., Mengu, A.P., Kırnap, M., Koç, H. and Sigan, Y.T. (2000) Serebral Palsili Olgularımızın Epidemiyolojik Ozellikleri. Turkiye Fiziksel Tip ve Rehabilitasyon Dergisi, 3, 46-48.

[22] Pueyo Benito, R. and Vendrell Gomez, P. (2002) Neuroimaging and Cerebral Palsy. Revue Neurologique, 35, $463-469$. 
Scientific Research Publishing (SCIRP) is one of the largest Open Access journal publishers. It is currently publishing more than 200 open access, online, peer-reviewed journals covering a wide range of academic disciplines. SCIRP serves the worldwide academic communities and contributes to the progress and application of science with its publication.

Other selected journals from SCIRP are listed as below. Submit your manuscript to us via either submit@scirp.org or Online Submission Portal.
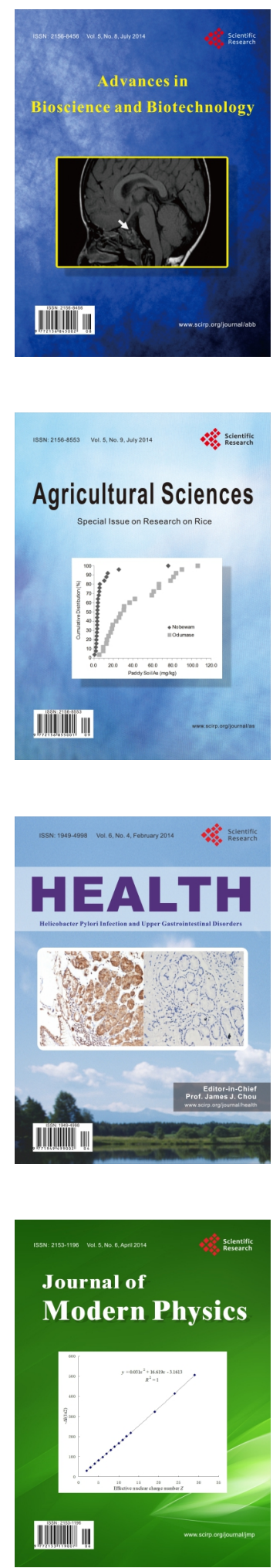
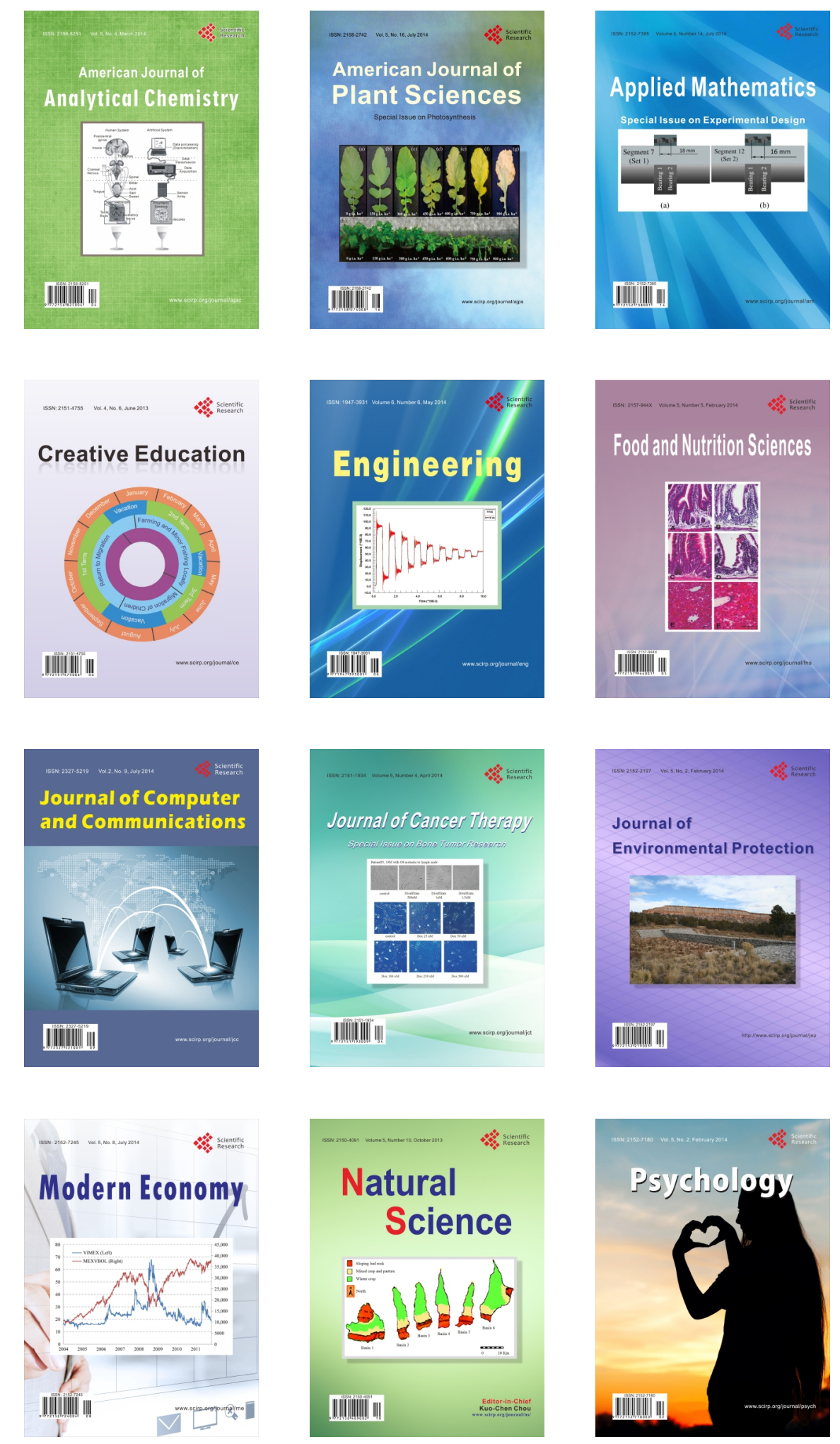